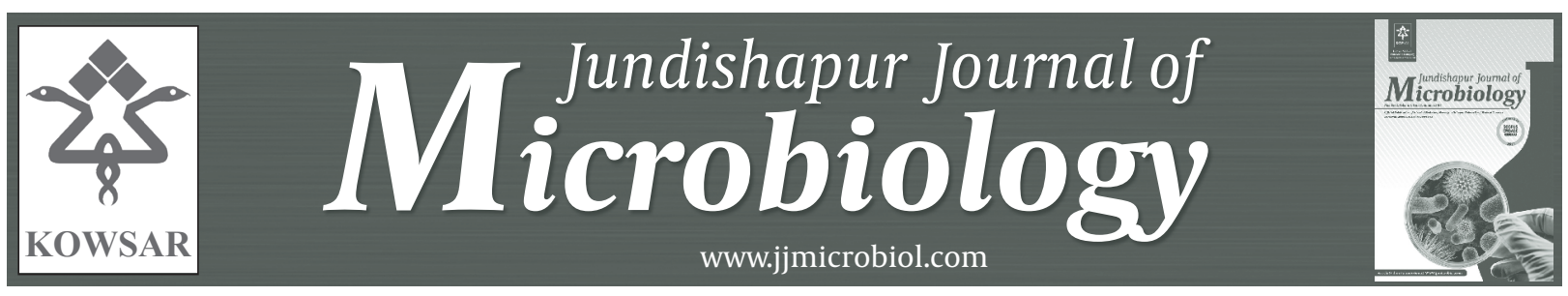

\title{
Diagnosis of Human Brucellosis by Blood Culture (BACTEC) and PCR Meth- od via Whole Blood and Serum
}

\author{
Mohammad Yousef Alikhani ${ }^{1}$, Seyyed Hamid Hashemi ${ }^{2,{ }^{*}}$, Zahra Naseri ${ }^{3}$, Safar Farajnia ${ }^{4}$, \\ Hadi Peeri-Dogaheh ${ }^{5}$ \\ ${ }^{1}$ Department of Microbiology, Faculty of Medicine, Hamedan University of Medical Sciences, Hamedan, IR Iran \\ 2 Department of Infectious Diseases, Hamedan University of Medical Sciences, Hamedan, IR Iran \\ ${ }^{3}$ Blood Transfusion Research Center, High Institute for Research and Education in Transfusion, Hamedan, IR Iran \\ ${ }^{4}$ Biotechnology Research Center, Tabriz University of Medical Sciences, Tabriz, IR Iran \\ ${ }^{5}$ School of Medicine, Ardebil University of Medical Sciences, Ardebil, IR Iran \\ ${ }^{*}$ Corresponding author Seyyed Hamid Hashemi, Division of Infectious Diseases, Sina Hospital, Hamedan, IR Iran. Tel: +988118274192, Fax: +988118276010, \\ E-mail:shahashemi@yahoo.com.
}

\section{A B S T R A C T}

Background: Brucellosis is the most common global zoonosis and an important public health problem in many parts of the world including Iran. Diagnosis of brucellosis is frequently difficult to establish and conventional methods are not always successful in identifying the organisms. Rapid detection of Brucella species by an automated blood culture system and Polymerase Chain Reaction (PCR) may lead to an earlier diagnosis and may improve patient management.

objectives: The current study aimed to evaluate PCR technique as a diagnostic tool for brucellosis in comparison to conventional bacteriological techniques.

Materials and Methods: A total of 50 patients suspected to have brucellosis were included in this study. All patients presented clinical signs compatible with brucellosis. Diagnosis was established by detecting a titer equal to or greater than 1:160 by the standard tube agglutination (STA)method. Blood samples and sera from the patients were tested by culture using BACTEC 9050 system and PCR using primer set to amplify a 223 bp region with in the gene coding for a $31 \mathrm{KD}$ Brucella antigen.

Results: Eleven (22\%) whole blood samples and 17 (34\%) serum samples out of 50 had positive PCR and 7 (14\%) patients had Brucella species grown in their cultures. Out of 43 blood culture negative samples, 10 (23.3\%) were positive with the serum PCR versus in $4(9.3 \%)$ with whole blood PCR.

Conclusions: The results suggest that the serum PCR assay is rapid and easy to perform and highly sensitive and specific, and it may therefore be considered a useful tool for diagnosis of human brucellosis.

Keywords: Brucellosis; Polymerase Chain Reaction; Blood; Culture

Copyright @ $\odot$ 2013, Ahvaz Jundishapur University of Medical Sciences; Published by Kowsar Corp.

Article type: Research Article; Received: 07 Apr 2012, Revised: 02 Jul 2012, Accepted: 11 Jul 2012; DOI: 10.5812/jjm.5073

Implication for health policy/practice/research/medical education:

The results of this study indicate that serum is the preferred clinical specimen for detecting Brucella by PCR.

PPlease cite this paper as:

Alikhani MY, Hashemi SH, Naseri Z, Farajnia S, Peeri-Dogaheh H. Diagnosis of Human Brucellosis by Blood Culture (BACTEC) and PCR Method via Whole Blood and Serum. Jundishapur J Microbiol.2013;6(3):248-51. DOI: 10.5812/jjm.5073

Copyright (C) 2013, Ahvaz Jundishapur University of Medical Sciences; Published by Kowsar Corp.

This is an Open Access article distributed under the terms of the Creative Commons Attribution License (http://creativecommons.org/licenses/by/3.0), which permits unrestricted use, distribution, and reproduction in any medium, provided the original work is properly cited. 


\section{Background}

Brucellosis is a major cause of zoonosis, and an important public health problem in many parts of the world, mostly in the Middle East. The disease is endemic in our area (1, 2). It is a zoonotic disease in which infection is transmitted to humans from domestic animals through direct contact or mostly through consumption of unpasteurized milk and contaminated dairy products. Five hundred thousand new cases are reported worldwide each year, but according to the World Health Organization, these figures notably underestimate the accurate occurrence of human disease (3). Since the clinical symptoms of human brucellosis are protean and nonspecific, laboratory confirmation by isolation of organism or detection of specific antibodies is necessary for the diagnosis.

Blood cultures stand for the "gold standard" of laboratory diagnosis. However, positive blood cultures occur in $10 \%-70 \%$ of suspected infections (4), depending on the duration, localization of the infection and the type of Brucella species. In addition, culturing is time-consuming. Automated blood culture systems may detect Brucella in less than seven days of incubation (5). However, the technology indeed is not available in most developing countries where the disease is prevalent. In addition, due to their comparatively long doubling time, Brucella species grow slowly on primary cultures and subcultures, while their inert biochemical profiles hamper fast identification of isolates(6). Diverset clinical pictures of the disease such as focal, relapsing, or chronic disease are characterized by low blood culture yields and pose special diagnostic problems $(7,8)$. Accordingly, detection of Brucella spp. in clinical specimens by cultures may still be difficult and take a long time.

Serological tests are more practical than culture techniques, while their specificities are low, especially in endemic areas or in people exposed to Brucella because of their profession. False-positive serological tests may also be caused by other illnesses such as tularemia, cholera, yersiniosis and salmonellosis, (4) while false-negative results may occur early in the course of the disease (9). As for other fastidious pathogens, molecular methodology offers an alternative way to diagnose brucellosis. Nucleic acid amplification techniques, like PCR, characterized by high sensitivity and specificity and short turnaround time can overcome the limitations of conventional methodology. Various blood samples including serum, whole blood, and buffy-coat have been used for molecular diagnosis of brucellosis $(10,11)$. Further investigation is needed to find the best specimen.

\section{Objectives}

The current study aimed to develop a diagnostic PCR assay and define the optimal clinical specimen for this test. For this purpose, peripheral blood samples, i.e., whole- blood and serum, from confirmed brucellosis cases were examined.

\section{Materials and Methods}

\subsection{Clinical Specimens}

During a 15- month period, 50 patients with brucellosis admitted in infectious disease section at Sina Hospital, Hamedan, Iran were included. All patients presented clinical symptoms compatible with those of brucellosis. Diagnosis was established by an anti-Brucella antibody titer equal to or more than 1:160 by the standard tube agglutination (STA) method. After obtaining informed consent, peripheral blood specimens were collected from patients. The study was approved by the Ethics Committee of Hamedan University of Medical Sciences.

\subsection{Microbiological Methods}

Blood cultures were processed with BACTEC 9050 (Becton Dickinson, USA), and between five to seven $\mathrm{ml}$. of blood from patients was inoculated in each of standard aerobic BACTEC bottle and incubated for seven days and subcultured whenever positive signal occurred by instrument. Suspected colonies were identified by colonial morphology, Gram-staining and standard biochemical (oxidase, catalase, production of $\mathrm{H} 2 \mathrm{~S}$ and urease) and agglutination test using specious specific antisera. At the end of the first week, bottles with negative growth index were kept for an additional three weeks and blind subcultures on Brucella base blood agar (Merck, German) were performed weekly. Cultures were considered negative for Brucella in the face of no growth after four weeks of incubation.

\subsection{Sample Processing for PCR}

Isolation of DNA from peripheral blood samples, included whole blood and serum carried out by commercial DNA extraction kit (BIONEER Co, Korea). The primers B4 (5'-TGGCTCGGTTGCCAATATCAA-3') and B5 (5'- CGCGCTTGCCTTTCAGGTCTG-3'), described previously by Bailey et al. (12), were used to amplify a target sequence of 223-bp within a gene code to produce a 31-kDa outer membrane protein specific to B. abortus, which is conserved in all Brucella species (13). PCR was performed using a $25 \mu \mathrm{L}$ volume reaction mixture containing $10 \mathrm{mM}$ tris- $\mathrm{HCl}(\mathrm{pH} 8.4), 50$ $\mathrm{mM} \mathrm{KCl}, 1.5 \mathrm{mM} \mathrm{MgCl} 2,200 \mu \mathrm{M}$ each deoxyribonucleotide triphosphate (dATP, dGTP, dTTP, dCTP, Fermentas Co), 0.5 $\mathrm{U}$ of Taq polymerase (Fermentas Co), oligonucleotide B4 and $\mathrm{B} 5$ (10 pM each) and $\mu \mathrm{G}$ of total DNA extracted was processed in a thermocycler (Eppendorf Co).

The cycling conditions consisted of initial denaturation at $95 \mathrm{C}$ for five minutes, followed by 35 cycles of $60 \mathrm{sec}-$ onds of template denaturation at $95^{\circ} \mathrm{C}$, 30 s of primer an- 
nealing at $60^{\circ} \mathrm{C}$, and $1 \mathrm{~min}$. of primer extension at $72^{\circ} \mathrm{C}$ and final extension at $72^{\circ} \mathrm{C}$ for seven minutes. Negative controls containing all of the reagents but lacking template DNA were routinely processed exactly as described above to monitor contamination with Brucella DNA and were negative in all experiments. Positive controls with genomic DNA isolated from a suspension of B. abortus B-19 were also included in each experiment. All PCRs were carried out in duplicate. The products ( $15 \mu \mathrm{l}$ from each reaction mixture) were analyzed by agarose gel (1.5\%) electrophoresis at $80 \mathrm{v}$ for 45 min stained with ethidium bromide and photographed on a UV Transilluminator.

\subsection{Statistical Analyses}

SPSS version 13.5 was employed to analyze the data, and a $P<0.05$ was considered statistically significant.

\section{Results}

Fifty patients including 27 males and 23 females, aged between eight and 77 years (mean, 43 years) were enrolled in the study. Thirty-three patients lived in a rural habitat and 44 patients referred exposure to animals or their products. Most patients had fever and night sweating (91\%), sever weakness (82\%), arthralgia (79\%) and backache $(67 \%)$. All patients gave a history of animal contact or ingestion of unpasteurized dairy products.

A total of 50 blood culture bottles were processed during the evaluation period, out of which, seven (14\%) were positive by BACTEC system (Table 1), with a mean detection time of six days. No growth was detected by BACTEC system in 43 (86\%) cases. All blood culture bottles were subcultured on sheep blood agar and chocolate agar plates. The media were incubated at $35^{\circ} \mathrm{C}$ in a $5 \% \mathrm{CO}$-enriched atmosphere and examined daily for four days. Suspected colonies were identified by standard tests. All isolates were identified as B.melitensis by agglutination test using species specific antisera. Seventeen (34\%) out of 50 brucellosis patients were PCR positive with both wholeblood and serum samples collected before treatment, 11 (22\%) were positive with whole-blood and 17 (34\%) with serum samples. Out of 43 blood culture negative samples, 10 (23.3\%) were positive with the serum PCR versus 4 (9.3 \%) with whole-blood PCR. Table 1 shows the diagnostic results of serum and whole blood PCR compared with rapid culture method for the 50 cases of brucellosis.

Table 1. Comparison of the Results of PCR-Based Assay with Microbiological Methods for the Diagnosis of Brucellosis

\begin{tabular}{lllll}
$\begin{array}{l}\text { Result of Routine } \\
\text { Procedure }\end{array}$ & Positive Serum PCR & Negative Serum PCR & $\begin{array}{l}\text { Positive Whole blood } \\
\text { PCR }\end{array}$ & Negative Whole-Blood PCR \\
\hline $\begin{array}{l}\text { Positive blood culture } \\
\text { Negative blood cul- }\end{array}$ & 7 & 0 & 7 & 0 \\
ture & 10 & 33 & 4 & 39 \\
Total & 17 & 33 & 11 & 39 \\
\hline
\end{tabular}

\section{Discussion}

As the clinical presentation of human brucellosis is quite nonspecific, it is needed to resort to isolation of the microorganism, by demonstrating high levels of specific antibodies or seroconversion, to make a precise diagnosis. However, all these methods have serious restrictions. In the current study, the authors evaluated the diagnosis of brucellosis before antibiotic treatment by culture, STA, and PCR methods. Although culture is the 'Gold standard' in microbial diagnosis, culture may sometimes be abolished by factors innate to the microbe itself in spite of strict laboratory measures undertaken. This view was supported by the use of PCR in the current study to identify ten culture negative patients with clinical symptoms of brucellosis. The antibody profiles for these patients showed high agglutination titers of Brucella-specific antibodies in most sera.

In the current study, the sensitivity of BACTEC to isolate Brucella was low (14\%) and the average incubation time for positive culture was relatively prolonged (six days). In other studies, the sensitivity of blood culture by
BACTEC varied between 30 to $90 \%$, and incubation time between three to seven days $(10,14-16)$. The reason for these discrepancies may be related to the discrepancies of disease stage in the population under study, in various reports, because the least rates of positive blood culture are seen in chronic brucellosis and the highest in acute febrile brucellosis. Likewise, the sensitivity of PCR may be affected by the stage and severity of the disease. This may explain the lower sensitivity of PCR in the current study compared to those of the previous studies. Moreover, the method of PCR may also be important. In a study conducted by Al-Ajlan et al. (17), the comparison of different methods of PCR ti diagnose brucellosis revealed that RTPCR was more sensitive than conventional PCR with 77.5\% sensitivity in whole blood and 60\% in serum.

Hedayati et al. (18) developed an improved PCR assay for the rapid and specific laboratory diagnosis of acute brucellosis from serum specimens of 30 Iranian patients. Alimoghadam et al. (19) determined optmization of PCR conditions to detect Brucella in 16 serum samples from Iranian patients with brucellosis. An important point in the current study was the higher sensitivity of PCR of se- 
rum compared to those of whole blood. Various results were observed in previous studies. Keid et al. (20) compared the PCR of whole blood and serum to diagnose canine brucellosis in Brazil. The higher sensitivity of PCR of whole blood (97\%) than that of serum (25.7\%) was reported. On the other hand, Zerva et al. (16) compared serum and whole blood samples to diagnose human brucellosis by PCR. They concluded that serum is the preferred clinical specimen for the molecular diagnosis of brucellosis.

Serum may have some preferences over whole-blood sample in PCR method. Several inhibitor substances such as anticoagulants, hemoglobin, and human DNA are present in whole blood but not in serum. Red blood cell lysis, washings by centrifugation, and measurement and adjustment of isolated DNA concentrations are not required (16). Overall, the use of serum is simple and shortens the time, and sensitivity may be increased. In conclusion, the current study results indicate that serum is the preferred clinical specimen to detect Brucella by PCR. The usefulness of this method to diagnose various stages of brucellosis including the currently problematic chronic and relapsing diseases needs further investigation.

\section{Acknowledgements}

The authors wish to thank Mrs. Z. Haidar-barghi and Mrs. H. Nazeri for their technical support.

\section{Financial disclosure}

None declared.

\section{Funding/Support}

This study was financially supported by the Research Deputy of Hamedan University of Medical Sciences.

\section{Authors' Contribution}

None declared.

\section{References}

1. Maleknejad P, Peeri-DoGaheh H, AmirZargar AA, Jafari S, Fatollahzadeh B. Diagnosis of brucellosis by use of BACTEC blood culture and confirmation by PCR. JVet Res. 2007;62(4):83-6

2. Refai M. Incidence and control of brucellosis in the Near East region. Vet Microbiol. 2002;90(1-4):81-110

3. World Health Organization. Fact sheet N173.1997; Available from: https://apps.who.int/inf-fs/en/fact173.html.

4. Moyer NP, Holcomb LA, Murray PR Baron EJ, Pfaller MA, Tenover FC, Youlken RH. Brucella. In: Moyer NP, Holcomb LA, Murray PR Baron EJ, Pfaller MA, Tenover FC, Youlken RH, editors.Manual of clinical microbiology.Washington DC: ASM Press; 1995. p. 549-55

5. Yagupsky P. Detection of Brucellae in blood cultures. J Clin Microbiol. 1999;37(11):3437-42

6. Koneman EW, Allen SD, Janda WM, Schreckenberger PC, Winn WC, Koneman EW, Allen SD, Janda WM, Schreckenberger PC, Winn WC. Brucella species. In: Koneman EW, Allen SD, Janda WM, Schreckenberger PC, Winn WC, Koneman EW, Allen SD, Janda WM, Schreckenberger PC, Winn WC, editors.Diagnostic microbiology.Lippincott: Philadelphia; 1997. p. 431-6

7. Ariza J. The perspective from the Mediterranean basin.Brucellosis: an update. Rev Med Microbiol. 1999;10:125-35

8. Ariza J, Corredoira J, Pallares R, Viladrich PF, Rufi G, Pujol M, et al. Characteristics of and risk factors for relapse of brucellosis in humans. Clin Infect Dis. 1995;20(5):1241-9

9. Wicher K, Milgrom F, Abeyounis CJ, Kano K. Brucella. In: Wicher K, Milgrom F, Abeyounis CJ, Kano K, editors.Principles of immunological diagnosis in medicine.Philadelphia: Lea \& Febiger; 1981. p. 97-101

10. Mitka S, Anetakis C, Souliou E, Diza E, Kansouzidou A. Evaluation of different PCR assays for early detection of acute and relapsing brucellosis in humans in comparison with conventional methods. J Clin Microbiol. 2007;45(4):1211-8

11. Yu WL, Nielsen K. Review of detection of Brucella spp. by polymerase chain reaction. Croat Med J. 2010;51(4):306-13

12. Baily GG, Krahn JB, Drasar BS, Stoker NG. Detection of Brucella melitensis and Brucella abortus by DNA amplification. J Trop Med Hyg. 1992;95(4):271-5

13. Mayfield JE, Bricker BJ, Godfrey H, Crosby RM, Knight DJ, Halling SM, et al. The cloning, expression, and nucleotide sequence of a gene coding for an immunogenic Brucella abortus protein. Gene. 1988;63(1):1-9

14. Araj GF. Update on laboratory diagnosis of human brucellosis. Int J Antimicrob Agents. 2010;36 Suppl 1:S12-7

15. Marei A, Boghdadi G, Abdel-Hamed N, Hessin R, Abdoel T, Smits $\mathrm{H}$, et al. Laboratory diagnosis of human brucellosis in Egypt and persistence of the pathogen following treatment. J Infect Dev Ctries. 2011;5(11):786-91

16. Zerva L, Bourantas K, Mitka S, Kansouzidou A, Legakis NJ. Serum is the preferred clinical specimen for diagnosis of human brucellosis by PCR. J Clin Microbiol. 2001;39(4):1661-4

17. Al-Ajlan HH, Ibrahim AS, Al-Salamah AA. Comparison of different PCR methods for detection of Brucella spp. in human blood samples. Pol J Microbiol. 2011;60(1):27-33

18. Hedayati MH, Adli MA, Nourozian D, Tabraei B, Ahmadi H, Siadat SD. Improved Diagnosis of Brucella In Human Serum Samples By Double PCR Assay. Iranian J Med Microbiol. 2007;1(3):47-51

19. Adlimoghadam A, Hedayati MH, Siadat SD, Ahmadi H, Nejati M, Vandyousefi J, et al. Optimization of PCR conditions for detection of human brucellosis from human serum samples. Res. J. Microbiol. 2008;3:352-358

20. Keid LB, Soares RM, Vasconcellos SA, Salgado VR, Megid J, Richtzenhain LJ. Comparison of a PCR assay in whole blood and serum specimens for canine brucellosis diagnosis. Vet Rec. 2010;167(3):96-9 